\title{
Claim Analysis of Construction Projects in Oman
}

\author{
Mohammed Al Mohsin \\ Built \&Natural Environment Department, Caledonian College of Engineering, Muscat, Oman \\ E-mail: almohsinmohammed@yahoo.com
}

\begin{abstract}
Claims are one of the problems that construction project may face. Claims might cause many affects such as payment delay, extension of time and work suspension. This paper aims to highlight claims in construction industry in Oman and factors affecting these claims, as a result of construction boom, claims get bigger attention due to the high effect on the main elements of construction management. Field study has been conducted to collect data required in claim concern. Data were collected through data collecting form designed for this purpose, collected data was for $\mathbf{4 5}$ projects with specific criteria. According to the analyzed data, it's been shown that the average of claims in construction projects is 2.6 claims per project, most of these claims are: extension of time effect, solved in negotiation manner, occurred in lump sum contracts. Owners are the first party "as sources of claims" with $42 \%$ of research sample over other sources like consultants, contractor and contract documents.
\end{abstract}

Keywords - Claims; Construction; Projects.

\section{INTRODUCTION}

Claims are one of the problems that construction project may face. Claims might lead to many consequences such as payment delay, extension of time and work suspension. Construction claims require both legal procedures and engineering abilities. It is possible to find professionals with these abilities; however, this is not enough to win a dispute. A good execution control system that permits the registration of all deviations from the original plans must be implemented. Construction claims should be made when there is an amount of money that has not been paid through the common, accepted procedures. A quantitative analysis must be prepared to decide if there is a return in the effort that needs to be executed for carrying out the claim. Probability of loss should be considered in the quantitative analysis. Qualitative variables, such as the possibility of losing the customer, should also be considered. A work breakdown structure is presented to help in the claiming procedure.

Sometimes issues occur in construction project that cannot be resolved among project participants. Such issues from contractors' perspective typical involve requests for additional money or time for work performed beyond that required by construction contract.

The basic cause of a dispute that often leads to a claim can be attributed to the fact that there was no meeting of the minds of the contracting parties. The end product of a claim is money and/or time that one party requests from another party during the course of a construction contract. The specific cause or causes are generally the alleged action, non-action, or wrong action by one or more participants in the construction project. The participants can include the owner, the architect/engineer, vendors, general contractors, or construction managers and/or subcontractors.

Effects and consequences of claims are the first justification for conducting many of researches different countries, furthermore, claim has to be discussed vertically to highlight factors affecting claims.

This paper aims to highlight claims in construction industry in Oman and factors affecting these claims, as a result construction boom, claims gets bigger attention due to the high effect on the main elements of construction management. Field study has been conducted to collect data required in claim concern.

\section{BACKGROUND}

The various related works done in this area of study are reviewed with different approaches to assess the claims and their impact on the construction Industry. Some reports and studies have been carried out for the analysis of construction claims.

Diekmann and Nelson (1985)[1] examined the frequency of occurrence of 427 separate construction claims which were experienced on 22 federally funded and administered construction projects. The data examined include various claim types, the frequency of their occurrence and the average cost of these claims. His study indicates that the largest proportion of change orders and modifications 
originate with the owner of the project or with those responsible to the owner.

Ren and Ugwu (2001) [2] reviewed the developments in claims management and highlights the deficiencies in current claims management approaches. His result was focusing on the need for improvement of the efficiency of claims negotiation and suggests the use of multiagent systems as an approach to achieve it. He assessed that disputes arise from the poor resolution of claims in the course of construction projects.

Kululanga et al (2001) [3] presented the principles that underly construction claim process and gives a generic framework that aims to facilitate measurement of construction claim process as one of the strategies for improving construction business processes. The paper also presents a survey of Malawian construction contractors' performance on the construction claim process framework. The results show a low awareness of such a construction claim process measuring instrument.

Scott and Harris(2004) [4] used a novel approach to understand how contractors justify their claims on construction contracts and how contract administrators are likely to assess them. This is done by encapsulating particular claim types into scenarios and interviewing not only contractors and contract administrators, but also claims consultants, to hear their views on how the situations represented by the scenarios should be resolved. The results show some good agreement, particularly on the problems of dealing with exceptionally adverse weather and with some aspects of concurrent delay assessment.

Iwamatsu et al (2008) [5] discussed unique characteristics of the implementation of construction work in Japan that are represented of this different use of terminology. These unique characteristics are considered as the result of a business culture that has developed through a combination of historical circumstance and the specific characteristics of Japan's construction market. The paper also examines the mechanism of dispute resolution, and considers specific details and changing trends in construction disputes using relevant statistical data.

Hassanein (2008) [6] aimed to provide a better insight into the status of claims management in general, and change order claims in particular, from the contractor's perspective with respect to the Egyptian industrial construction sector, as they proved to be the main cause of claims in this sector. The results demonstrated that claims management in the Egyptian industrial sector has been suffering from a variety of obstacles, including lack of proper notification procedures in public contracts and poor documentation management.

Change orders had been actually lost due to poor documentation. Oral change orders were present in approximately 76 percent of the projects; half of which resulted in loss of rights due to improper documentation, which was largely attributed to the lack of contract awareness of the site team, and to the "fear of consultant phenomenon".

\section{TYPES OF CLAIMS}

Contractor's claims may be of three major kinds:

\section{A. Common law claims}

These arise from causes which are outside the express terms of a contract. They relate to breaches by the Employer or his agents of either implied or express terms of the contract, for example; if the Employer in some way hindered progress of the Works or if the architect were negligent in carrying out his duties, resulting in loss to the contractor.

\section{B. Ex gratia claims}

These have no legal basis but are claims, which the contractor considers the Employer has a moral duty to meet, e.g., if he has seriously under-priced an item whose quantity has been increased substantially because of the variation which will in consequence cause him considerable loss. The Employer is under no obligation to meet such 'hardship claims' but may be prepared to do so, on grounds of natural justice or to help the contractor where otherwise he might be forced into liquidation.

\section{Contractual claims}

These arise from express terms of a contract and form by far the most frequent kind of claim. They may relate to any or all of the following:

(a) Fluctuations; (b) variations; (c) extensions of time; and (d) loss and/or expense due to matters affecting regular progress of the works [7].

Mainly the above types of claims are the most common, other types can be seen below [8]:

1. Different Site Conditions Claims: refers to some physical aspect of the project or its site that differs materially from the indicated by the contract documents or that is of an unusual and differs materially from the conditions ordinarily encountered.

2. Acceleration claims which occur when a contractor's work is expedited to complete a particular work activity earlier than planned.

3. Difference in Pricing and Measuring Claims: which deal with the disagreement regarding measurements at the final stage in the construction. Also, these claims include the differences in pricing by the contractor and the owner of some of the materials. As well, the change and the extra work usually create some differences in pricing.

4. Damage Claims represented by three types; the first actual damages where the owner is entitled to the cost of completing the job or of remedying those defects that are remediable. The second types is liquidated damages where they are agreed upon in advance by the parties as compensation for the breach of a contract, where the actual damages caused by the breach are incapable of accurate estimation. The third is delay damages where a contractor may be entitled to recover damages for losses due to delays.

\section{CLAIMS EFFECTS}

Claims can lead to tremendous effects upon the type of claim and the reason has led for occurrence, these effects can be summarized in table 1 . 


\section{CAuses of Claims}

Claims can be originated in many forms with respect to the sources of them, these sources are the main parties of contract and its documentation, a number of reasons can be seen for each source. Causes and their sources are shown in table 2 .

TABLE 1: EFFECTS INDUCED DUE TO CLAIMS

\begin{tabular}{|l|l|}
\hline \multicolumn{1}{|c|}{$\begin{array}{c}\text { Type of } \\
\text { claim }\end{array}$} & \multicolumn{1}{c|}{ Effect } \\
\hline $\begin{array}{l}\text { Contractual } \\
\text { claims }\end{array}$ & Poorly written contracts \\
\hline $\begin{array}{l}\text { Delay } \\
\text { claims }\end{array}$ & $\begin{array}{l}\text { These delays represent problems in the contractor's } \\
\text { organization such as lack of management or } \\
\text { financial capability, sub-contractor caused delays } \\
\text { etc. }\end{array}$ \\
\hline $\begin{array}{l}\text { Change } \\
\text { claims }\end{array}$ & $\begin{array}{l}\text { The Client responsible of changing in original } \\
\text { design. According to this change will be dispute of } \\
\text { delay and increasing cost of change. }\end{array}$ \\
\hline $\begin{array}{l}\text { Extra work } \\
\text { claims }\end{array}$ & $\begin{array}{l}\text { Misunderstanding between the client and } \\
\text { contractor. The contractor believes that he is } \\
\text { performing extra work, while the owner believes } \\
\text { the work was part of original contract. } \\
\text { - Different measurement pricing claims. } \\
\text { - The different measurements in final stages affect } \\
\text { the plan of the time and price in the project }\end{array}$ \\
\hline $\begin{array}{l}\text { Damage } \\
\text { claims } \\
\text { client cantrith do anything about the safety of } \\
\text { project. } \\
\text { - Different site conditions claims. } \\
\text { - The Contractor found difficult conditions in site } \\
\text { which is not expected to face. Therefore delays } \\
\text { and needs special equipment to operate. }\end{array}$ \\
\hline
\end{tabular}

TABLE 2: CAUSES OF Claims [9]

\begin{tabular}{|c|c|}
\hline Source & Claims Reasons \\
\hline Owner & $\begin{array}{l}\text { 1. Lack of expertise } \\
\text { 2. Long line of authority in project organization } \\
\text { 3. Sequence of work directed by owner } \\
\text { 4. Delayed approvals of schedules and change } \\
\text { orders } \\
\text { 5. Slow change order processing } \\
\text { 6. Failure to obtain permits } \\
\text { 7. Irrelevant milestone dates in documents }\end{array}$ \\
\hline $\begin{array}{l}\text { Contract } \\
\text { Documents }\end{array}$ & $\begin{array}{l}\text { 8. Inadequate scheduling clauses } \\
\text { 9. Drawings not indicating work interfaces } \\
\text { 10. Permitting responsibilities vague } \\
\text { 11. Milestone dates and interface clauses } \\
\text { unreasonable } \\
\text { 12. Leverage for enforcement of schedule } \\
\text { specification } \\
\text { 13. Coordination inadequately specified } \\
\text { 14. Power of individual party vaguely specified }\end{array}$ \\
\hline Consultant & $\begin{array}{l}\text { 15. Lack of expertise in schedule management } \\
\text { 16. Quality control } \\
\text { 17. Inadequate record keeping } \\
\text { 18. Inadequate schedule updates and progress } \\
\text { monitoring } \\
\text { 19. On-site coordination } \\
\text { 20. Job progress meetings }\end{array}$ \\
\hline Contractor & $\begin{array}{l}\text { 21. Noncompliance with specifications } \\
\text { 22. Non adherence to site instructions } \\
\text { 23. Non updating of schedules } \\
\text { 24. Reluctance to cooperate and coordinate } \\
\text { 25. Failure to meet milestone dates } \\
\text { 26. Noncompliance to permit requirements }\end{array}$ \\
\hline
\end{tabular}

\section{CLAim RESOLUTION}

All claims, in different stages, whether it's disagreement, dispute, protest, and claim; claim resolution is possible. The method of resolution depends on the types of claim, size, effects and consequences.

\section{A. Negotiation}

Negotiation involves both parties to the dispute sitting down, discussing both sides of the issue, and reaching agreement on an appropriate resolution. This is the most efficient and least expensive method of resolution and does not rely on any outside support. Negotiation should be attempted as soon as the dispute surfaces to avoid creating an adversarial relationship between the contractor's field personnel and those of the owner. Early negotiation may prove successful if attempted before the parties have had a chance to formulate strong positions regarding the dispute.

\section{B. Mediation}

Mediation is an assisted negotiation process in which settlement discussions are facilitated by a neutral third party. Both the contractor and the owner may agree to bring in an outside mediator, or it may be required by the construction contract. General Conditions require mediation prior to taking a dispute to arbitration. The individual selected as mediator must be acceptable to both parties. As a consequence, this person must be credible and knowledgeable of the issues in question. The mediator listens to both parties' positions and attempts to help them reach a consensus. The mediator does not render any decision on the issues, but serves as an intermediary between the parties to the dispute. Most mediation sessions last only one day, but occasionally they may extend into a second day.

\section{Arbitration}

Arbitration is a formalized alternative to litigation in which the disputing parties present their case to a neutral third party, called the arbitrator, who is empowered to make a decision. Arbitration can be binding or nonbinding. Binding arbitration means that the arbitrator's decision is final, and nonbinding arbitration means that either party may pursue litigation after arbitration. If the losing party in nonbinding arbitration decides to litigate, the arbitration award may be entered as evidence in court. Both the contractor and the owner may agree to take their dispute to arbitration, or it may be required by the construction contract. Article 4.6 of the AlA General Condition requires the use of binding arbitration to resolve disputes. Arbitration generally is a more efficient process than litigation because it is quicker and less expensive. Even so, arbitration of large, complicated cases can still be time consuming and expensive. In addition, arbitrators typically have more expertise in the technical subject matter under dispute than do judges.

\section{Litigation}

Litigation means referring the disputed issue to a court for resolution. This involves hiring legal counsel, preparing necessary documentation, and scheduling an appearance before a judge. Most contractors and owners attempt to resolve their disputes without resorting to litigation, but it might be used as a last resort. Litigation is not an expedient 
means of dispute resolution. It can take years before the matter proceeds to trial, and if appeals are made, the final result will be delayed further [9].

\section{METHODOLOGY}

Claims is the topic of which associated to many aspects of construction industry for instance it's related horizontally to all phases of construction projects despite that claims occurred in construction phase but avoidance of claims is already there. On the other hand, claims are related vertically to all activities in construction and other elements of cost management as time, cost, and quality. Claims are related to other psychological factors due to the fact claim is a parts of conflict happening in construction projects.

This study mainly consist of three parts; the first represented by theoretical part and literature review, in this part the researcher is attempting to narrate the whole picture of claims in theoretical basis and details in addition to reviewing some researches and studies have been published in correspondence with the topic of this research.

The second part is the process of data collection; it has been decided that the conclusions of this research would be based on actual data collected from finished project in Oman; hence, the actual data would enhance and consolidate these conclusions. For this purpose, the researcher has designed a unified data collection form to be filled up for each project of research sample using projects' record kept with consultants. The main condition of these projects that is the total cost must more than 500,000 OR (about 1,358,700 \$) to highlight the importance of this research for both public and private sector, project cost is the main criteria to screen projects with respect to the size of project, assuring that the size of project is would be economically effective. Claims of projects of such size would have clear impact on construction industry. Research sample consist a number of projects in different owners and categories.

The third part is analysing data collected and summing up the finding out disclosed through analysis; analysis tools comprise the following:

- calculating the mean for the number claims per each project,

- Calculating coefficient of correlation between No. of claims per project and other factors as actual cost, delay time, and types of project.

- Percentages of occurrence are also calculated to clarify the details of claims in Oman construction industry.

\section{RESULTS AND DISCUSSION}

As the research methodology is being in progress, research sample was a number of public and private projects in Oman, 45 records were collected for 45 projects in Oman, all of these construction projects were in different fields of construction industry as; residential, commercial, industrial buildings projects, highway project, and sewage treatment plants.

As per data collected and analysed the results for each part of claims will be shown and discussed separately.

\section{A. Number of Claims}

The total numbers of the claims that occurred in 45 projects were 119 claims with average of 2.64 claims per each project and standard deviation of 1.68 . However, the minimum number of claims is 1 , and the maximum of the claims 7. As far as concern to the number of claims of construction projects in Oman, this number seems to be too less as compared with other countries for many reasons represented by the calm nature of this industry in Oman.

Many trials have been conducted to check whether the No. of claims is correlated to type of contract, delay time, actual cost. All of these trials have shown insignificant correlation. The interpretation of this insignificancy is because of that No. of claims is not correlated to one variable; it's correlated to these entire factor and may be more that researchers have to study them.

\section{B. Effects of Claims}

According to the data collected, it's found that the most effect in construction projects in Oman that if there is extension of time in percentage of $75 \%$, w here $15 \%$ of the effects were in work suspension as effects of the claims but $10 \%$ of the effects happen when there is payment delay.

The main indication has come out through effects of claims is the degree of delay in construction projects where the average delay was for research sample is $43.25 \%$ giving high attention to both standard deviation(81.09) and max delay is $294.525 \%$, the wide range of delay in these projects makes a sense of infeasibility of discussing these values. Furthermore, correlation coefficient between delay percentage and the no. of claims was 0.053 which is insignificant correlation. It's obvious that the main reason of delay in construction projects is not because of claims in these projects, the coefficient of correlation between them indicates so.

In general, extension of project duration (not delay) is the effect No. 1 has come out due to claims in addition to many effect as work suspension and payment delay for contractors.

\section{Claims resolution}

The results show that $84 \%$ of the research sample which have claims can be solved by negotiation, where $15 \%$ of the claims can be solved by mediation. On the other hand, $4 \%$ of the claims can be solved by arbitration and $2 \%$ of the claims in Oman solved by legislation.

This result seems to be logical because of the high cost in solving claims in other method other than negotiation, it's clear that claims resolution by negotiation is the best way to solve any problems, moving to higher level of claim resolution is already highly costed and takes time that is also a cost. Negotiation is one of the most common approaches used to manage disputes, this type of settlement involves deep discussion between the two side of claim till reaching an agreement on an appropriate resolution.

\section{Types of contracts and claims}

Research sample mostly are Lump sum contract with a percentage of $80 \%$, where premeasuring contract takes $11 \%$ from the percentage. Moreover, bill of quantity has $6 \%$ where civil contract and traditional contract have same percentage which $4 \%$. Even that there is no clear 
relationship between the types of contract and No. of claims, it's difficult to link claims to the types of contract because of that types of contract is not the only variable affecting claims.

\section{E. Causes of Claims Reasons}

As per results, owners are the first source of claims with $41.36 \%$, for contractor is 21.47 for consultants 20.96 , and for contract documents is $16.23 \%$, this result would be reflected in form of claims submitted by contractors to clients due to their responsibility of claims generating.

Both contractor and the owner represent about two third sources of claims. This fact can lead to another which is the problem of contractor selection and how far affects the process of project execution. As project goes on smoothly with less problems, success is the inevitable results achieved in these project.

For owner side according to the results, the delayed approvals of schedules and change orders is the majority of causes of claims in 17.28 which is the highest percentage for causes of claims. Once owners still controlling their projects with less degree of awareness, it's difficult to meet projects objectives. Features of less degree of qualification of owners represented in shortage of qualified human resources, shortage of finance, bad control of budget. Under budgeting, all of these factors are mainly lead to claims originated by owners; this issue has become more pronounced if the second cause in owner list appears which is "lack of expertise". The two causes of claims under owner list are in compliance of each other to conclude that owners have to improve the abilities of construction management in all phases and particularly in study, design, construction phases. These phases consist of crucial decisions have to be made by owners, if any decision has come in wrong way or out of scientific approach, no one can expect meeting project objectives.

The first three causes are; Delayed approvals of schedules and change orders (17.28\%), Lack of expertise $(6.81 \%)$, and Slow change order processing $(6.81 \%)$. all of these causes are initiated by owner in addition to the fact that he had the privilege of $41.36 \%$ of claims.

High attention to be given to construction projects studying by owners for the reasons that they have to be qualified to manage their project. In case of inability to manage these project owner has to move to another method of procurements as a solution of lack of qualification in construction project management, moreover, owner has to ask for support in high specification project.

As a comparison between the Omani and Egyptian case with respect to claims, it has been seen that documentation problems are highly effective of construction projects in Egypt, while this problem hasn't the same impact.

Change order problem is one of the similar causes of claims in Oman and some of other cases discussed in the background of this paper.

More details about sources and reasons leading to claims are shown in table 3
TABle 3: PERCENTAGES OF ClAIM REASONS AND SOURCES

\begin{tabular}{|c|c|c|}
\hline Source & Claims Reasons & $\%$ \\
\hline \multirow{8}{*}{ Owner } & 1. Lack of expertise & 6.81 \\
\hline & $\begin{array}{l}\text { 2. Long line of authority in project } \\
\text { organization }\end{array}$ & 5.76 \\
\hline & 3. Sequence of work directed by owner & 2.09 \\
\hline & $\begin{array}{l}\text { 4. Delayed approvals of schedules and } \\
\text { change orders }\end{array}$ & 17.28 \\
\hline & 5. Slow change order processing & 6.81 \\
\hline & 6. Failure to obtain permits & 0.52 \\
\hline & $\begin{array}{l}\text { 7. Irrelevant milestone dates in } \\
\text { documents }\end{array}$ & 2.09 \\
\hline & Total for owner & 41.36 \\
\hline \multirow{8}{*}{$\begin{array}{c}\text { Contract } \\
\text { Documents }\end{array}$} & 8. Inadequate scheduling clauses & 3.14 \\
\hline & $\begin{array}{l}\text { 9. Drawings not indicating work } \\
\text { interfaces }\end{array}$ & 5.24 \\
\hline & 10. Permitting responsibilities vague & 1.05 \\
\hline & $\begin{array}{l}\text { 11. Milestone dates and interface } \\
\text { clauses unreasonable }\end{array}$ & 1.05 \\
\hline & $\begin{array}{l}\text { 12. Leverage for enforcement of } \\
\text { schedule specification }\end{array}$ & 1.57 \\
\hline & 13. Coordination inadequately specified & 3.14 \\
\hline & $\begin{array}{l}\text { 14. Power of individual party vaguely } \\
\text { specified }\end{array}$ & 1.05 \\
\hline & Total for contract documents & 16.23 \\
\hline \multirow{7}{*}{ Consultant } & $\begin{array}{l}\text { 15. Lack of expertise in schedule } \\
\text { management }\end{array}$ & 2.62 \\
\hline & 16. Quality control & 5.24 \\
\hline & 17. Inadequate record keeping & 5.24 \\
\hline & $\begin{array}{l}\text { 18. Inadequate schedule updates and } \\
\text { progress monitoring }\end{array}$ & 2.09 \\
\hline & 19. On-site coordination & 2.09 \\
\hline & 20. Job progress meetings & 3.66 \\
\hline & Total for consultant & 20.94 \\
\hline \multirow{7}{*}{ Contractor } & 21. Noncompliance with specifications & 4.19 \\
\hline & 22. Non adherence to site instructions & 3.14 \\
\hline & 23. Non updating of schedules & 4.19 \\
\hline & $\begin{array}{l}\text { 24. Reluctance to cooperate and } \\
\text { coordinate }\end{array}$ & 4.19 \\
\hline & 25. Failure to meet milestone dates & 4.71 \\
\hline & $\begin{array}{l}\text { 26. Noncompliance to permit } \\
\text { requirements }\end{array}$ & 1.05 \\
\hline & Total for contractor & 21.47 \\
\hline
\end{tabular}

\section{CONCLUSIONS AND RECOMMENDATION}

Upon the result discussed above the following conclusions can be considered:

1. The main source of claims in construction projects (in Oman) is owner contributing of $41.36 \%$.

2. Contractors and consultants are contributing as a source of claims in equal percentage (about $20 \%$ ).

3. Claims occurred in all projects for various causes with a mean of 2.6 (standard deviation; 1.68) for each project 
4. Lack of owner experience which is reflected in term of bad response to contractor notes.

5. The highest effect of claims is appeared in form of time extension despite that the relationship between No. of claims and delay time of projects is insignificant.

6. No. of claims per project is has insignificant correlation to many factors for that multi correlation test would be beneficial to assure factors affecting claims in Oman.

Some aspects haven't been discussed in this research, it's recommended based on the discussion of it to go through the following:

1. Owners have to evaluate their ability to manage construction projects.

2. Choosing the best delivery plan of project to fulfill their objectives.

3. Development and improvement is required for owners to manage construction projects objectives assessed in advance.

4. High level coordination between owners and contractors.

5. Restudying selection of general contractors for construction projects, process and criteria of selection are to be reviewed for the best relationship between owner and contractor to minimize claims and their consequences

For future works it's recommended to study other aspects of claims collecting all factors affecting claims. Mathematical model is applicable for claims and these factors.

\section{REFERENCES}

[1] James E. Diekmann, M. ASCE and Mark C. Nelson, "Construction Claims: Frequency and Severity", Journal of Construction Engineering and Management, Vol.111, Issue 1, pp. 74-81, March/April 1985.

[2] Z. Ren, C. J. Anumba, and O. O. Ugwu "Construction claims management: towards an agent-based approach" Engineering Construction and Architectural Management Volume 8, Issue 3, pages 185-197, June 2001

[3] G. K. Kululanga, W. Kuotcha, and R. McCaffer, "Construction Contractors' Claim Process Framework" Journal of Construction Engineering and Management, Volume 127, Issue 4, pp. 309-314, 2001

[4] Steve Scott and Richard Anthony Harris, "United Kingdom Construction Claims: Views of Professionals" Journal of Construction Engineering and Management, Volume 130, Issue 5, pp. 734-741, September/October, 2004.

[5] Jun Iwamatsu, Tetsukazu Akiyama, and Kazuyoshi Endo3, "Construction Claims and Disputes and the Business Culture of Construction in Japan" Journal of professional issues in engineering Education and practice, Vol 134, Issue 1, pp. 119-127, January 2008.

[6] Amr A.G. Hassanein, Waleed El Nemr, "Claims management in the Egyptian industrial construction sector: a contractor's perspective" journal of Engineering, Construction and Architectural Management, Vol.15, Issue: 5, Page: 456 - 469, 2008

[7] Jack Ramus, Simon Birchall, and Phil Griffith, Contract Practice for Surveyors, 4th edition, Elsevier Linacre House, Jordan Hill, 2006.

[8] Ivor Seeley, Quantity Surveying Practice, 2nd edition McMillan Press Ltd. London, 1997.

[9] Edward R. Fisk, P.E, Construction Project Administration, 4th edition, Prentice hall, Englewood Cliffs, USA, 2000.

[10] S. M. Metev and V. P. Veiko, Laser Assisted Microtechnology, 2nd 